\title{
NEEM PRODUCTS AGAINST COCONUT INSECT PESTS
}

\author{
By \\ S. Sadakathulla ${ }^{1}$
}

\begin{abstract}
Three field experiments were conducted to find out the efficacy of neem products against the damage of rhinoceros beetle to coconut palm and termite damage to coconut palm and plaited leaves. The application of cither neem seed powder + sand (1:2) or neem seed kernel powder + sand (1:2) @ $150 \mathrm{~g}$ mixture per palm in the bases of three leaf axils in the crown, were found more effective against rhinoceros damage. Spraying of neem oil $5 \%$ or neem seed kernel extract $20 \%$ from the base and up to, $2 \mathrm{~m}$ height on the truck protected the palm from termites. Spraying with copper sulphate $1 \%$ and-then neem oil $5 \%$ or copper sulphate $1 \%$ and then neem seed kernel extract $20 \%$ on plaited coconut leaves was found efficacious in protecting plaited coconut leaves for more than six months even when the plaited leaves were kept on the bare ground having persistent live termite colony throughout the year.
\end{abstract}

\section{INTRODUCTION}

Among the major insect pests of coconut (Cocos nucifera Lin), rhinoceros beetle (Otyctes rhinoceros L.) was found attacking palms in serious proportion with persistent occurrence in ail countries where coconut is grown. Besides coconut, rhinoceros beetle attacks pineapple, sugarcane, palmyrah, date palm, red oil palm, tali pot palm and royal palm. But coconut has been found to be the most favored of ail palms by the beetle (Dhileepan, 1986. Sundara Babu, 1986).

The adult rhinoceros burrows and remains in leaf axils of the spindle leaves in the crown of the palm causing damage to, the developing leaves resulting in characteristic "V" or wedge shaped appearance in unfolded leaves. Though the damage was prevalent throughout the year to, varying degrees, significantly greater damage was recorded during May, June and August months as against the least in February (Sakadathulla and Ramachandran, 1991-b). The beetles also bore into the soft tissues of the bud/cabbage. More fronds; were attacked by a single beetle in older palms, since they have more compact crown. The beetle attacks the unopened spathes and can cause up to $10 \%$ reduction in yield. The injury and the bore $\mathrm{h}$ le made by this beetle also serve as points of entry of other equally important pest viz., the red palm weevil, Rhynchophorus ferrugineus $\mathrm{F}$. The conventional control of the damage by $\mathrm{HCH} 10 \%$ + sand (1:1) mixture in three leaves axil bases found effective (David and Kumaraswami, 1982). The integrated management of this pest was reviewed by Sundarababu (1986), Sadakathulla and Ramachandran (1990-b; 1990-c) found the application of naphthalene balls or phorate $10 \% \mathrm{G}+$ sand (1:2) equally effective as that of the conventional method.

The subterranean pest termite, Odontotermes obesus Ramb, is an important pest of coconut seedling in the nursery, newly planted, seedling, growing palms in the plantation and plaited coconut leaves. The incidence will be more in sandy loam soils and on soils other than sandy, this pest appears to be attracted by the husk of the seednut in the nursery and the dry under-composed organic wastes; applied to the main plantation. As early as 1958 . Nirula et al estimated $20 \%$ loss of coconut seedlings due to termite attack. In older palms, the earthen gallery extends up to 3 to $4 \mathrm{~m}$ height of the trunk during summer. In young plantations, the termite galleries even reaches the leaf bases in the crown and damage them, resulting the premature shedding of functional leaves. The damage to the bark of the tree renders it prone to the infestation of bark borer beetle Xyleborus sp., the worst enemy

1 Professor, Agricultural Entomology, Coconut Research Station, Tamil Nadu Agricultural University, Veppankulam, Tamil Nadu, South India. 
of grown up palms. The termites also attack the plaited leaves in the thatched roof and skeletonize them. The alternate hosts of termite are sugarcane, groundnut, chillies, guava (Prasad and Rao, 1988).

In view of the considerable loss caused to the palm by these insects pests three experiments were conducted at Coconut Research Station, Veppankulam during 1990-92 to find out the efficacy of neem products against the rhinoceros beetle and termite damage.

\section{MATERLALS AND METHODS}

\section{a. Rhinoccros beetle (O. rhinoceros)}

The field experiment was laid out at Coconut Research Station, Veppankulam in randomized block design, replicated four times with eight treatments; comprising four plant products and 3 chemicals viz., neem seed powder (NSP) + sand (1:2 ratio). Neem seed kernel powder (NSKP) + sand (1:2) (g- $150 \mathrm{~g} / \mathrm{palm}$, neem cake powder (NCP) + sand (1:2) $100 \mathrm{~g} / \mathrm{palm}$. neem cake powder $(\mathrm{NCP})+$ sand (1:2)@ $150 \mathrm{~g} / \mathrm{palm}$, Klorocin (SBP = Standard Bleaching Powder) + sand (1:3) @ 200 g/palm, HCH 10\% + sand (1:1) @150 g/palm, Napthalene balls@3 nos/palm and untreated control. The coconut palms which where constantly attacked by rhinoceros beetle where screened and selected for the experiment and recorded, total number of leaves in the crown and leaves attacked by the rhinoceros beetle prior to imposing the treatments. The individual chemical mixture was applied in the leaf bases of 3 innermost leaves in the crown. Three napthalene balls per palm were applied to the base of 3 innermost leaves in the crown @ each per leaf base. The treatment with naphthalene balls alone was repeated 45 days after the first round. Periodical observations on the damage of leaves in the crown by $O$. rhinoceros were continued for three months and the percent damage is different treatments assessed.

\section{b. Termite (O. obesus)}

Two field experiments Where conducted during 1991- 1992 summer season at Coconut Research Station. Veppankulam.

i) The experiment on palms was laid out in randomized block design, replicated thrice with seven treatments viz. 1) aldrin $30 \mathrm{EC} @ 0.15 \%$; 2) HCH 50\% WP, 0.25\%; 3) Chlordane 20 EC @ $0.1 \%$. 4) Neem oil (NO) 5\%, 5) Neem seed kernel extract (NSKE) 20\%; 6) Cashewnut shell oil (CNSO) $80 \%$ and 7) untreated control. Each treatment consisted of 10 palms of 22 years old showing five carthen gallery of $O$. obesus both on the base and trunk of the palms to varying heights at the time of experiment layout. The spraying was done using a hand operated high volume rocker type of sprayer by drenching to the point of run off from the base of the palm and soil around and the trunk up to $2 \mathrm{~m}$ height from ground level. Periodical observations at fortnightly intervals after the treatment were recorded up to seven months.

The cashewnut shell oil cannot be sprayed as such with a sprayer; hence one part of kerosine was added to four parts of cashewnut shell oil for aiding smooth spraying as suggested by Pillai et al (1983). For other treatments, teepal was added @ 1 ml per 1 of spray fluid.

ii) The experiment on plaited leaves Was laid out in randomized block design replicated thrice with 11 treatments, viz. 1) aldrin $0.15 \%$, 2) $\mathrm{HCH} 0.25 \%, 3$ ) Chlordane $0.1 \%$, 4) neem oil 5\%,5) neem seed kernel extract $20 \%, 6)$ cashewnut shell oil $80 \%, 7)$ copper sulphate $\left(\mathrm{CuSo}_{4}\right) 1 \%$; 8) copper sulphate $1 \%$ and neem oil 5\%; 9) copper sulphate $1 \%$ and neem seed kernel extract 20\%, and 10) copper sulphate $1 \%$ and cashew nut shell oil $80 \%$ and 11) untreated check. For each treatment, five numbers of plaited coconut leaves $(1 \mathrm{~m}$ length $\mathrm{x} 0.4 \mathrm{~m}$ width each) were used. The emulsion sprays for the treatments 1 to 7 were sprayed on both the sides of the plaited leaves. For the treatments 8-10, copper sulphate $1 \%$ was sprayed first on the plaited leaves and air dried in shade for 30 minutes. The individual treatment (T8-T10) was sprayed. These plaited coconut leaves after treatments were 
individually kept on the bare ground, where the live termite colony was persistent throughout the year. Periodical observations at fortnightly interval on the termite infestation on the plaited leaves under treatment were recorded.

\section{RESULTS AND DISCUSSION}

\section{a) Rhinoceros:}

All the chemical treatments were found significantly superior against rhinoceros damage. Among them, the treatment i0th the application of three naphihalene balls in three leaf bases in the crown was found more effective recording significantly lesser damage $(8.6 \%)$. The results agree with the earlier findings of Gurmit Singh (1987) and Sadakaihulla and Ramachandran (1990-b: 1990-c). The next best treatment was the application of $\mathrm{HCH} 10 \%+$ sand mixture $(9.9 \%)$. closely followed by the treatment with neem seed powder + sand $(10.1 \%)$ and neem seed kernel powder + sand $(10.7 \%)$ (Table 1). Since Klorocin + sand mixture (10.1\%) caused phytotoxicity in the leaves at the points of contact of the chemical, this cannot be recommended though it is on par with neem seed powder + sand and neem seed kernel powder + sand and neem seed kernel powder + sand mixture application for the efficacy.

The mixture of neem seed powder or neem seed kernel powder + sand 91:2) can be well utilized as it is locally available and cheaper for the effective management of rhinoceros beetle in coconut palm.

b) For termite control both in the nursery and planted seedlings, cultural and chemical measures have been suggested (Beal and Smith 1964): Bees et al., 1966). Application of 2-3 aluminium phosphidc tablets in the hole of the termitarium and plugging the hole air tight to kill the entire colony including, the queen also found effective (Rangajaran et al, 1985). Sirkar (1486) advised the painting, of the trunk up to $1 \mathrm{~m}$ height of older coconut palms with coal tar or lime. Sadakathulla and Ramachandran (1990a; 1991a) found out the efficacy of either aldrin $0.15 \%$ or $\mathrm{HCH} 0.25 \%$ or chlordane $0.1 \%$ spray against the termite both on the palm and plaited coconut leaves.

The results of the present studies indicated the best efficacy of spraying, with cither neem oil $5 \%$ or neem seed kernel extract $20 \%$ treatment as that of the spray with aldrin $0.15 \%$, HCH $50 \%$ WP $0.25 \%$ and chlordane $0.1 \%$ on the base and up to $2 \mathrm{~m}$ height of the trunk of the coconut palm and spraying cither with copper sulphate $1 \%$ and then cashew nut shell oil $80 \%$ or copper sulphate $1 \%$ and then neem oil $5 \%$ or copper sulphate $1 \%$ and neem seed kernel extract $20 \%$ on the plaited coconut leaves against $O$. obesus for more than 6 months even when the treated plaited leaves were kept on the bare ground having, the persistent live termite colony throughout the year (Table 2).

Spraying with $\mathrm{CuSo}_{4} 1 \%$ and neem oil $5 \%$ or $\mathrm{CuSo}_{4}$ and neem seed kernel extract $20 \%$ was found equal in efficacy as that of the treatment with $\mathrm{CuSo}_{4} 1 \%$ and then cashewnut shell oil $80 \%$. The neem products can be easily and cheaply substituted in the place of cashewnut shell oil for the protection of palm and preservation of plaited coconut leaves from the ravages of the termites,

\section{CONCLUSION}

The locally available cheaper plant product neem seed powder + sand 0:2) or neem seed kernel powder + sand (1:2) @ $150 \mathrm{~g}$ mixture in the leaf base of three inner most leaves in the crown was effective and may be well fitted in the integrated pest management programme of the rhinoceros beetle in coconut plantation.

Spray of neem oil $5 \%$ or neem seed kernel extract $20 \%$ on the base of up to $2 \mathrm{~m}$ height of the trunk of coconut palm was found as effective against termites as that of spraying with either aldrin $0.15 \%$ or $\mathrm{HCH} 0.25 \%$ or chlordane $0.1 \%$. 
Spraying with $\mathrm{CuSo}_{4} 1 \%$ and neem oil $5 \%$, or $\mathrm{CuSo}_{4} 1 \%$ and neem seed kernel extract $20 \%$ on plaited coconut leaves was found equal in efficacy as that of the spraying with $\mathrm{CuSo}_{4} 1 \%$ and then cashewnut shell oil $80 \%$ in the presentation of plaited coconut leaves.

\section{REFERENCES}

Beal, R.H. and Smith, V. K. (1996) Progress report of granular formulations of insecticides for controlling termites J. Econ. Entomol. 57:771

Bees, H. A., Ota, A. K. and Kawanishi, C. (1966) Persistence of soil insecticides for control of subterranean termites. J. Econ. Enthomol. 59:911 - 915.

David. B N. and Kurmaraswami, T. (1982). Coconut pests Elements of Economic Entomology. Popular Book Dept. Madras p. 92 - 98

Dhileepan. K. 1986. Pests of oil palm and their management strategies in India. Trg. \& Prdn. Tecbnology of oil palm. CPCRI. Kasaragod. p. 11- 13

Gurmit Singh (1987) Naphthalene balls for the protection of coconut and oil palm against Oryctes rhinoceros. The Planter 63: 286 - 292

Nirula, K. K., Antony. J and Menon. K. P. V. (1958) Some investigations on the control of termites. Indian Coconut J. 7: 26 - 29

Pillai. C. K. S., Venkataswamy, M. A., Satyanarayana, K. G. and Rahatgi, P. K. (1983) Preserving coconut leaf thatch: A simple method. Indian Coconut J. 14 (8):3 - 6

Prasad, P. R. and Rao. K. P. (1988). How termites ravage fields. The Hindu dt. Dec. $7^{\text {th }}$ 1988: p 24

Rangarajan. A. V. Chelliah. S. and Javaraj, S. (1985). Pest management in ficid crops and stored products. Techl. Extn. Bull. TNAU. Coimbatore. pp. 32

Sadakathulla, S. and Ramachandran. T. K. (1990-a) Evaluation of insecticides against termite. Odontoterines obesus Romb. (Termitidae: Isoptera) attacking palm and plated leaves of coconut. Indian Coconut J. 21 (1). 11 - 13

Sadakathulla. S. and Ramachandran. T. K. (1990-b). A novel method to control rhinoceros beetle. Orives rhinoceros L. in coconut. Indian Coconut J. 21 (7 \& 8): 10 - 12

Sadakathulla, S. and Ramachandran, T. K. (1990-c) Efficacy of naphthalene balls in the control of rhinoceros beetle attack in coconut. Cocos (Sri Lanka) 8: 23 - 25.

Sadakathulla, S. and Ramachandran, T. K. (1991-a) Termites should no longer worry you in coconut plantations. Indian Hort. 36 (3): 24.

Sadakathulla, S. and Ramachandran, T. K. (1991-b) Management of rhinoceros in coconut plantations The Planter 67 (782): 197 - 199.

Sirkar, B.B. (1986). Control of coconut pests of North Eastern Hill region. Indian Coconut J. 16 (2): $3-8$.

Sundarababu, P.C. (1986). Coconut rhinoceros beetle and its management. Pest and Disease Management (Ed. S. Javaraj) TNAU, Coimbatore. pp. 76 - 80. 
Table 1

Efficacy of neem seeds against Rhinoceros beetle

\begin{tabular}{|c|l|c|}
\hline S. No. & \multicolumn{1}{|c|}{ Treatments } & Pooled mean Damage (\%) \\
\hline 1. & Neem seed powder (NSP) + sand (1:2) & 10.2 \\
2. & Neem seed kernel powder (NSKP) + sand (1:2) & 10.7 \\
3. & Neem cake powder alone & 16.7 \\
4. & Neem cake powder (NCP) + sand (1:2) & 15.3 \\
5. & Klorocin (SBP) + sand (1:3) & 10.1 \\
6. & HCH 10\% + sand (1:1) & 9.9 \\
7. & Naphthalene balls @ 3 balls/palm & 8.6 \\
8. & Untreated control & 19.4 \\
& CD (P = 0.05) & 1.2 \\
\hline
\end{tabular}

Table 2

Efficacy of chemicals against termite damage

\begin{tabular}{|c|c|c|c|}
\hline \multirow{2}{*}{ S.No. } & \multirow{2}{*}{ Treatments } & \multicolumn{2}{|c|}{ Mean Protection on $(\%)$} \\
\hline & & Palm Trunks & Plaited leaves \\
\hline \multirow[t]{2}{*}{1.} & Aldrin30\%@0.15\% & 100.0 & 97.3 \\
\hline & & $(90.0)$ & $(80.6)$ \\
\hline \multirow[t]{2}{*}{2.} & HCH 50\% WP @ 0.25\% & 100.0 & 96.7 \\
\hline & & $(90.0)$ & $(79.6)$ \\
\hline \multirow[t]{2}{*}{3.} & Chlordane 20\% EC @ 0.1\% & 100.0 & 97.1 \\
\hline & & $(90.0)$ & $(80.3)$ \\
\hline \multirow[t]{2}{*}{4.} & Neem Oil (NO) $5 \%$ & 94.6 & 80.0 \\
\hline & & $(75.6)$ & $(63.4)$ \\
\hline \multirow[t]{2}{*}{5.} & Neem seed kernel extract (NSKE) 20\% & 92.7 & 79.0 \\
\hline & & $(74.6)$ & $(62.7)$ \\
\hline \multirow[t]{2}{*}{6.} & Cashew-nut shell oil (CNSO) $80 \%$ & 68.6) & 79.7 \\
\hline & & & $(63.2)$ \\
\hline \multirow[t]{2}{*}{7.} & Copper Sulphate (CuSo4 1\%) & - & 75.6 \\
\hline & & & $(60.4)$ \\
\hline \multirow[t]{2}{*}{8.} & $\mathrm{CuSoE}_{4} 1 \% ; \mathrm{NO} 5 \%$ & - & 99.7 \\
\hline & & & $(87.3)$ \\
\hline \multirow[t]{2}{*}{9.} & $\mathrm{CuSo}_{4} 1 \%$; NSKE $20 \%$ & - & 98.2 \\
\hline & & & $(82.4)$ \\
\hline \multirow[t]{2}{*}{10.} & $\mathrm{CuSo}_{4} 1 \% ; \mathrm{CNSO} 80 \%$ & - & 100.0 \\
\hline & & & $(90.0)$ \\
\hline \multirow[t]{3}{*}{11.} & Untreated control & 0 & 0 \\
\hline & & $(4.8)$ & $(4.8)$ \\
\hline & $\mathrm{CD}(\mathrm{P}=0.05)$ & 2.72 & 5.46 \\
\hline
\end{tabular}

- Treatment not included Figures in parenthesis are arc sine transformed values. 